\title{
PENINGKATAN PERANCANGAN SISTEM INFORMASI MERCHANDISE INSIDE LOMBOK BERBASIS WEBSITE MENGGUNAKAN API WHATSAPP
}

\author{
Habib Ratu Perwira Negara ${ }^{1}$, Ahmad ${ }^{2}$, K Komang Wira Aditya ${ }^{3}$ \\ 1,2,3 Universitas Bumigora Mataram \\ E-mail: habib.ratu27@gmail.com¹, ahmad@universitasbumigora.ac.id ${ }^{2}$, wiraaditya55@gmail.com³
}

\begin{abstract}
Aims to be able to help PT. Lombok Media Utama (Inside Lombok) in managing all its merchandise catalogs on the website and making it easier for customers who want to buy merchandise to input the purchase format using the WhatsApp API. This activity is in the form of making a website using the prototyping method and training carried out by the team by providing training to the Inside Lombok admin staff in the form of directions on the flow of using this website application, the participants involved are the inside Lombok admin staff. From the results obtained after testing using BlackBox Testing and evaluation of satisfaction, quite satisfactory results were obtained where the admin managed to manage merchandise products easily, and customers could also use the features on the website smoothly to fill in the format with the Whatsapp API feature to be more efficient.
\end{abstract}

Keywords: web, prototyping, javasript, e-commerce.

\begin{abstract}
Abstrak
Bertujuan untuk dapat membantu PT. Lombok Media Utama (Inside Lombok) dalam mengelola semua katalog merchandisenya pada website dan mempermudah pelanggan yang ingin membeli merchandise dalam menginput format pembelian dengan menggunakan API WhatsApp. Adapun kegiatan ini berupa pembuatan website dengan menggunakan metode prototyping dan pelatihan yang dilakukan oleh tim dengan memberikan pelatihan kepada admin staff Inside Lombok berupa arahan tentang alur penggunaan aplikasi website yang dibuat ini, peserta yang terlibat adalah admin staff inside lombok. Dari hasil yang didapat setelah melakukan pengujian menggunakan BlackBox Testing dan evaluasi kepuasan didapat hasil yang cukup memuaskan dimana admin berhasil mengelola produk merchandise dengan mudah, serta pelanggan juga bisa menggunakan fitur pada website dengan lancar hingga melakukan pengisian format dengan fitur API Whatsapp menjadi lebih efisien.
\end{abstract}

Kata kunci: Web; prototyping; javascript; e-commerce.

\section{PENDAHULUAN}

PT. Lombok Media Utama atau yang biasa dikenal oleh masyarakat yang berada di Lombok yaitu Inside Lombok, Inside Lombok merupakan sebuah perusahaan yang bergerak dibidang informasi yang menyebarkan sebuah informasi berupa berita-berita terbaru. Informasi yang kami sajikan tidak hanya berasal dari jurnalis Inside Lombok melainkan juga bersumber dari informasi laporan warga, sehingga masyarakat sangat dimungkinkan untuk berkontribusi menghadirkan isu-isu terkini di sekitarnya.

Inside Lombok berbasis di Lombok oleh karena itu menjadi sangat dikenal oleh masyarakat yang berada di lombok dengan tujuan untuk lebih mempererat hubungan dengan 
masyarakat sekitar, maka Inside Lombok memutuskan untuk membuat sebuah Merchandise Inside Lombok berupa Baju, Celana, dan lain-lain.

Pada PT. Lombok Media Utama (Inside Lombok) memiliki sebuah toko merchandise yang berbasis digital yang dimana penempatan katalog untuk setiap produknya berada di Instagram dan pembelian harus menghubungi nomor whatsapp admin Inside lombok merchandise.

PT. Lombok Media Utama (Inside Lombok) berkolaborasi dengan Universitas Bumigora dalam sebuah program Kuliah Kerja Praktek / Magang yang dilaksanakan oleh mahasiswa Universitas Bumigora untuk mengatasi permasalahan yang dialami oleh Inside Lombok.

Berdasarkan masalah yang diperoleh, tim menemukan bahwa informasi mengenai produk yang dijual dan proses pemesanan yang menjadi masalah utama. Tim melihat bahwa tidak adanya website untuk khusus katalog yang menampung semua produk pada website. Untuk itu perlu adanya pengembangan website untuk merchandise produk yang ada pada Inside Lombok Merchandise. Hal ini sejalan dengan hasil penelitian yaitu dengan menggunakan website sebagai media penerima informasi yang dapat diperoleh pada perangkat elektronik seperti komputer maupun handphone, dengan mengakses website melalui handphone kita dapat membuka website dimana saja dan kapanpun untuk mendapatkan sebuah informasi (Siregar, 2018). Saat ini sistem informasi telah membuat hidup manusia menjadi lebih mudah dengan adanya pemanfaatan media internet komunikasi menjadi tidak terbatas dan tidak adanya hambatan geografis hingga hambatan waktu yang dimana kita dapat mendapat informasi kapanpun dan dimanapun (Websitedi et al., 2020).

Selanjutnya masalah yang dihadapi berupa format order dalam pembelian produk masih harus diketik secara manual, maka tim menawarkan solusi dengan menggunakan API Whatsapp, lalu pembelian akan diarahkan pada whatapps langsung dengan format yang sudah ada pada website. Pemakaian API WhatsApp ini berguna agar semua kegiatan yang berlangsung pada website dapat langsung terhubung langsung ke WhatsApp berupa pesan yang sudah memiliki format dari website yang dapat memudahkan pengguna dalam bertransaksi maupun komunikasi langsung dengan Admin website (Aprilia, 2020).

Sejalan dengan penelitian tentang "Sistem Informasi Absensi Berbasis Website Menggunakan API WhatsApp dengan Metodologi Incremental" pada SMP Negeri 29 Pekanbaru yang membahas tentang permasalahan tentang teknologi dalam pengolahan data absensinya. Disini pengolahan datanya masih konvensional, serta lambatnya atau kurang berkerja secara maksimal untuk pengolahan data yang dirasakan user. Karena itu 
membutuhkan waktu yang cukup lama dan pengguna juga membutuhkan integrasi langsung terhadap orang tua tentang ketidakhadiran siswa agar menghindari perilaku buruk yang terjadi di sekolah. Berdasarkan permasalahan tersebut maka dibuatlah sebuah sistem informasi absensi dengan memakai bahasa pemprograman PHP dan MySQL sebagai database. Dalam hal perancangan sistem ini memanfaatkan metodologi incremental. Metodologi incremental sangat sesuai untuk developer yang mempunyai turnover yang tinggi sehingga dapat dilakukan secara paralel tanpa menunggu tahapan lain selesai. Setiap ketidakhadiran siswa akan dikirimkan melalui pesan WhatsApp kepada orang tua. Sistem ini diharapkan dapat membantu guru dalam melakukan absensi, memudahkan tata usaha dalam penyimpanan data absensi, serta memudahkan orang tua dalam memantau kehadiran siswa di sekolah. Hasil pengujian gap analysis mengalami perpindahan dari kuadran 1 menuju kuadran 2, hal ini menunjukkan sistem absensi yang dirancang telah sesuai dengan keinginan pengguna(Aprilia, 2020). Kemudian penelitian tentang "Sistem Informasi Penjualan Menggunakan CRUD Berbasis Website Di CV. Wahyu Abadi Berguna" terkait Wahyu Abadi Berguna tidak memiliki penjualan produknya melalui internet dan hanya bisa melayani transaksi yang dilakukan melalui telepon. Adapun perangkat lunak pendukung yang di gunakan adalah Photoshop, Sublime text, Notepad, Notepad++ sebagai pembangun website penjualan. Hasil yang diharapkan dengan adanya system berbasis web ini, yang sudah terkoneksi dengan database, tentunya sangat mempermudah pengolahan penjualan barang dan sangat membantu sekali dalam pemasaran produk, karena setiap informasi yang akan di berikan kepada semua konsumen bisa lebih cepat, akurat dan tentunya dengan biaya yang sangat murah (Websitedi et al., 2020). Selanjutnya pada penelitian tentang "Perancangan Website Sebagai Media Promosi Dan Penjualan Produk" Kegiatan promosi sangat penting dalam memasarkan suatu produk. Sedangkan dalam promosi kita memerlukan suatu media yang dapat membantu promosi sampai kepada target konsumennya. Agar dapat memberikan pelayanan yang baik bagi konsumen sekaligus mempromosikan produk Edene Sayangku Cafe \& Bakery, dirancang suatu media informasi berupa website yang bertujuan untuk mempromosikan serta menjual produk yang ada pada toko Edene Sayangku Cafe \& Bakery (Siregar, 2018).

Berdasarkan latar belakang dan permasalahan yang diperoleh, maka manfaat dari kegiatan ini pada PT. Lombok Media Utama (Inside Lombok) supaya Staff Admin dapat dengan mudah mengelola website dari halaman dashboard admin yang sudah tersedia. Serta pelanggan dapat terhubung langsung dengan admin Inside Lombok Merchandise di Whatsapp untuk memproses pembelian. 
Adapun tujuan yang ingin dicapai dari kegiatan ini yaitu bertujuan supaya bisa membantu PT. Lombok Media Utama (Inside Lombok) untuk mengatur semua katalognya pada website dan mempermudah pelanggan yang ingin membeli merchandise dalam menginput format pembelian.

\section{METODE}

Jenis kegiatan ini adalah pembuatan website penjualan merchandise dan pelatihan. Pelaksanaan dilaksanakan selama 23 Hari tepatnya pada tanggal 1 Agustus 2021 hingga tanggal 23 Agustus 2021, peserta yang terlibat adalah admin staff inside lombok. Adapun materi yang disampaikan pada saat kegiatan berlangsung dalam pembuatan website ini yaitu:

1) PHP

PHP merupakan bahasa scripting server-side yang dimana sebuah bahasa pemrograman yang digunakan untuk mengembangkan situs web statis atau situs web dinamis atau aplikasi Web (Saragih, 2020). PHP singkatan dari Hypertext Preprocessor, yang sebelumnya disebut Personal Home Pages (Lesmono, 2018).

Karena php merupakan scripting server-side maka jenis bahasa pemrograman ini nantinya script/program tersebut akan dijalankan/diproses oleh server(Pradipta, 2019). Berbeda dengan javascript yang client-side.

PHP adalah bahasa pemrograman umum yang berarti php dapat disematkan ke dalam kode HTML, atau dapat digunakan dalam kombinasi dengan berbagai sistem templat web, sistem manajemen konten web, dan kerangka kerja web (Wahyudi et al., 2019).

\section{2) MySQL}

MySQL adalah sebuah software yang berfungsi untuk membuat dan mengelola berbagai informasi yang ada pada database di dalam sebuah server dengan bahasa pemrograman SQL(Susilo, 2018).

\section{3) JavaScript}

JavaScript adalah salah satu bahasa pemrograman yang paling banyak digunakan dalam kurun waktu dua puluh tahun ini(Peni et al., 2013). Bahkan JavaScript juga dikenal sebagai salah satu dari tiga bahasa pemrograman utama bagi web developer:

- HTML: Memungkinkan Anda untuk menambahkan konten ke halaman web(Mariko, 2019).

- CSS: Menentukan layout, style, serta keselarasan halaman website(Hasan \& Nasution, 2018). 
- JavaScript: Menyempurnakan tampilan dan sistem halaman web(Ruswiansari \& Rozi, 2018).

\section{4) BlackBox Testing}

Untuk tahap terakhir, penulis menggunakan blackbox testing untuk menguji apakah input dan output pada sistem telah memenuhi kebutuhan terkait dengan internal program (Lesmono, 2018).

\section{5) Metode Prototyping}

Menurut Sommerville (Pradipta, 2019), Metode prototyping adalah metode yang bertujuan agar peneliti mendapatkan gambaran aplikasi yang akan dibangun melalui tahap pembangunan aplikasi prototype terlebih dahulu yang akan dievaluasi oleh user. Sistem prototype memperbolehkan pengguna untuk mengetahui bagaimana sistem berjalan dengan baik(Anis Rohmadi, 2020).

\section{6) API Whatsapp}

Sebuah aplikasi yang dapat membuat interaksi antara customer dan perusahaan berjalan dengan lebih efisien(Aprilia, 2020). Kata API sendiri memiliki artian Application Programming Interface yang berisi serangkaian kode yang nantinya akan terkoneksi dengan software perusahaan(Abidatul Izzah, 2021).

\section{7) E-Commerce}

Electronic commerce atau ecommerce adalah segala aktivitas jual beli yang dilakukan melalui media elektronik. Meskipun sarananya meliputi televisi dan telepon, kini ecommerce lebih sering terjadi melalui internet (Nasir \& Solikin, 2019).

Secara umum pelaksanaan kegiatan ini dilakukan terdiri dari:

\section{Pembuatan}

Langkah pembuatan menggunakan Software Development Life Cycle (SDLC) yang dimana pada saat perancangan aplikasi ini penulis menggunakan metode Prototype yang bertujuan untuk memungkinkan staff admin Inside Lombok tersebut untuk melakukan evaluasi terhadap website merchandise yang sudah dirancang di awal dan mencoba sebelum diimplementasikan. Dalam pembuatan aplikasi ini menggunakan aplikasi pendukung yaitu Visual Studio Code yang dimana semua ide akan diimplementasikan berupa sebuah bahasa pemrograman PHP. Adapun metode prototype yang diusulkan ini terbagi menjadi beberapa aktifitas kerja yang bisa disebut wilayah tugas yang dimana wilayah tugas terbagi menjadi tujuh wilayah tugas dalam melaksanakan kegiatan antara lain sebagai berikut: 
1. Pengumpulan Kebutuhan

Staff admin dan perancang website bersama-sama mendefinisikan format dari seluruh aplikasi serta garis besar dari sistem informasi yang akan dibuat.

2. Membangun Prototype System

Dengan membuat perancangan sementara yang berfokus pada penyajian kepada Staff admin Inside Lombok, seperti rancangan inputan dan format output pada aplikasi. Setelah itu dilakukan evaluasi pada perancangan sistem, pada tahap evaluasi ini dilakukan oleh Staff admin Inside Lombok, ini bertujuan untuk melanjutkan ketahap selanjutnya jika evaluasi sudah selesai dan sesuai. Adapun format input data yang digunakan adalah seperti terlihat pada gambar di bawah ini.

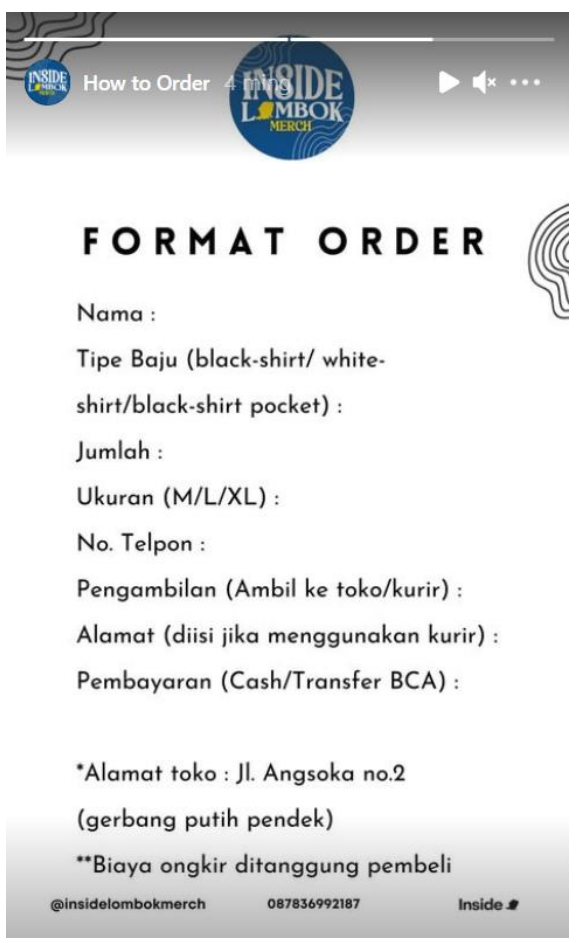

Gambar 1. Format Order

Pada Gambar 1, data format order ini diambil dari instagram Inside Lombok Merchandise, yang dimana pelanggan harus mengetik sendiri format pembelian di chat Whatsapp admin Inside Lombok Merchandise.

3. Mengkodekan Sistem 
Pada tahap prototyping sudah diterima dan disepakatan, maka selanjutnya diterjemahkan ke dalam bahasa pemrograman yang sesuai. Pada perancangan aplikasi ini menggunakan bahasa pemrograman PHP dan JavaScipt, kemudian untuk Database yang digunakan adalah MySQL.

4. Menguji Sistem

Setelah sistem aplikasi telah menjadi sebuah website, kemudian melakukan proses uji coba aplikasi website merchandise.

5. Evaluasi Sistem

Staff admin Inside Lombok akan mencoba terlebih dahulu website yang telah dibuat, dan untuk menentukan apakah website merchandise telah sesuai dengan yang client harapkan.

\section{Pelatihan}

Pelatihan ini dilakukan oleh tim dengan memberikan pelatihan kepada admin staff Inside Lombok berupa arahan tentang alur penggunaan aplikasi website yang dibuat ini.

\section{HASIL DAN PEMBAHASAN}

\section{a. Pembuatan}

1) Analisis Kebutuhan Pengguna

a) Admin

Administrator adalah seseorang yang mempunyai wewenang atau akses penuh terhadap sistem website. Admin memiliki wewenang dan juga tanggung jawab kepada data dan sistem, yang dimana admin ini merupakan admin pada bagian marketing website katalog merchandise Inside Lombok. Admin memiliki tugas utama yaitu mengatur data produk dan data pemesanan.

b) Pelanggan

Pelanggan merupakan orang yang ingin membeli sebuah produk yang dihasilkan oleh perusahaan pemilik dari website itu. Dalam sistem website ini, pelanggan dapat melihat produk yang tersedia, melakukan pemesanan.

2) Membangun Prototype

a) UML Use Case Diagram

Sesuai dengan analisis kebutuhan pengguna, maka seperti gambar 2 merupakan akses atau hal apa saja yang dapat dilakukan oleh admin dan pelanggan saat mengakses website Inside Lombok Merchandise. 


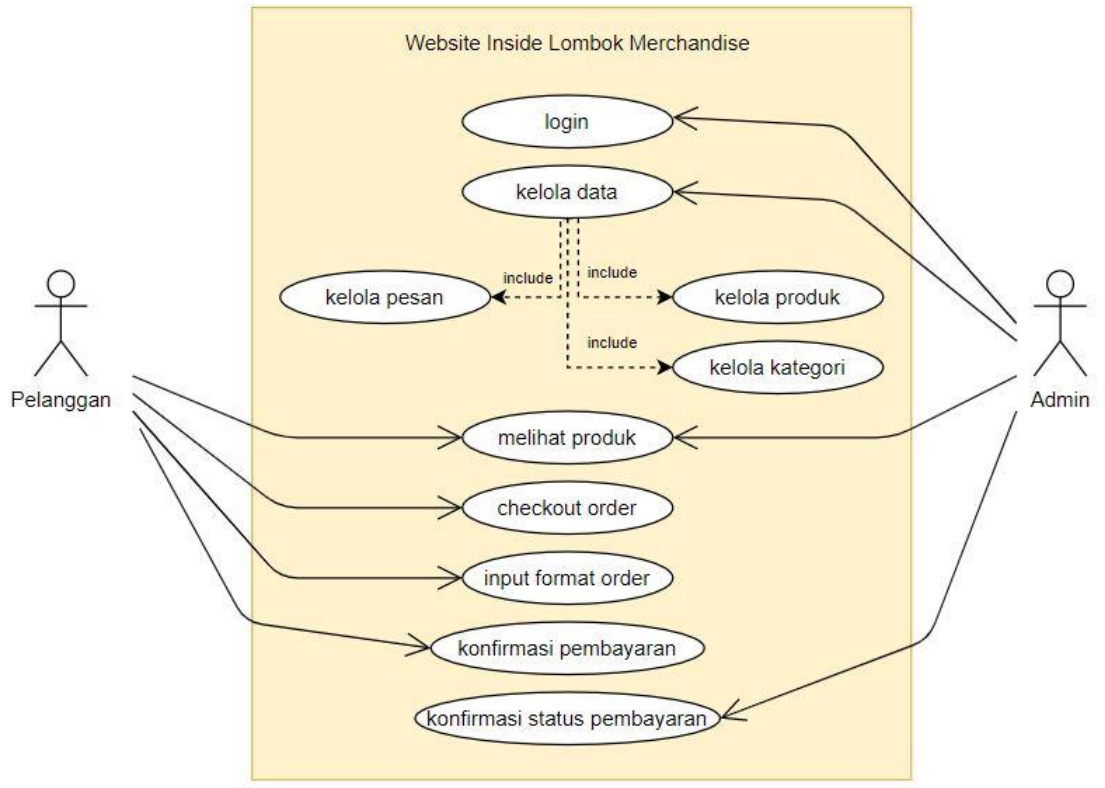

\section{Gambar 2. Alur Use Case Diagram}

b) Database

Pada gambar 3 terdapat 4 tabel database dalam pembuatan website antara lain:

a) Tabel categories

Pada tabel ini akan menampung semua jenis kategori produk yang diinputkan oleh admin.

b) Tabel messages

Pada tabel ini akan menyimpan riwayat dari pelanggan jika telah melakukan pemesanan yang akan dihubungkan dengan whatsapp admin.

c) Tabel post

Pada tabel ini akan menyimpan data dari postingan produk yang telah dimasukkan oleh admin seperti produk baju, celana, dan lain-lain. Maka post ini akan tampil dihalaman utama website.

d) Tabel config

Pada tabel ini menyimpan data config dari website. 


$\mathbf{v}$ insidemerch insidemerch_categories
8 id : int(6) unsigned
( category : varchar(50)

\begin{tabular}{|c|}
\hline $\mathbf{v} \mathbf{0}$ insidemerch insi \\
\hline 8 id : int(6) unsigned \\
\hline (1) config : varchar(150) \\
\hline (1) value : text \\
\hline
\end{tabular}

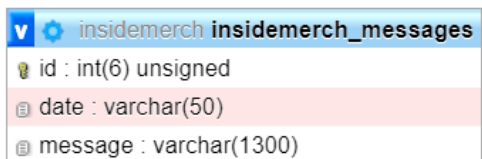

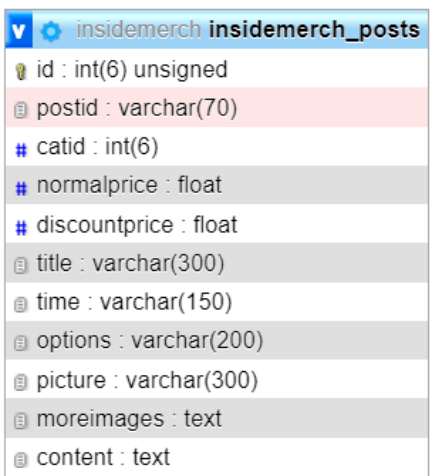

\section{Gambar 3. Database Website Inside Lombok Merchandise}

3) Mengkodekan Sistem

Setelah ditentukannya alur dari sistem yang ingin dibuat, maka selanjutnya kita akan mengimplementasikannya kedalam bahasa pemrograman PHP untuk memulai membangun website, dengan menggunakan Database berupa MySQL.
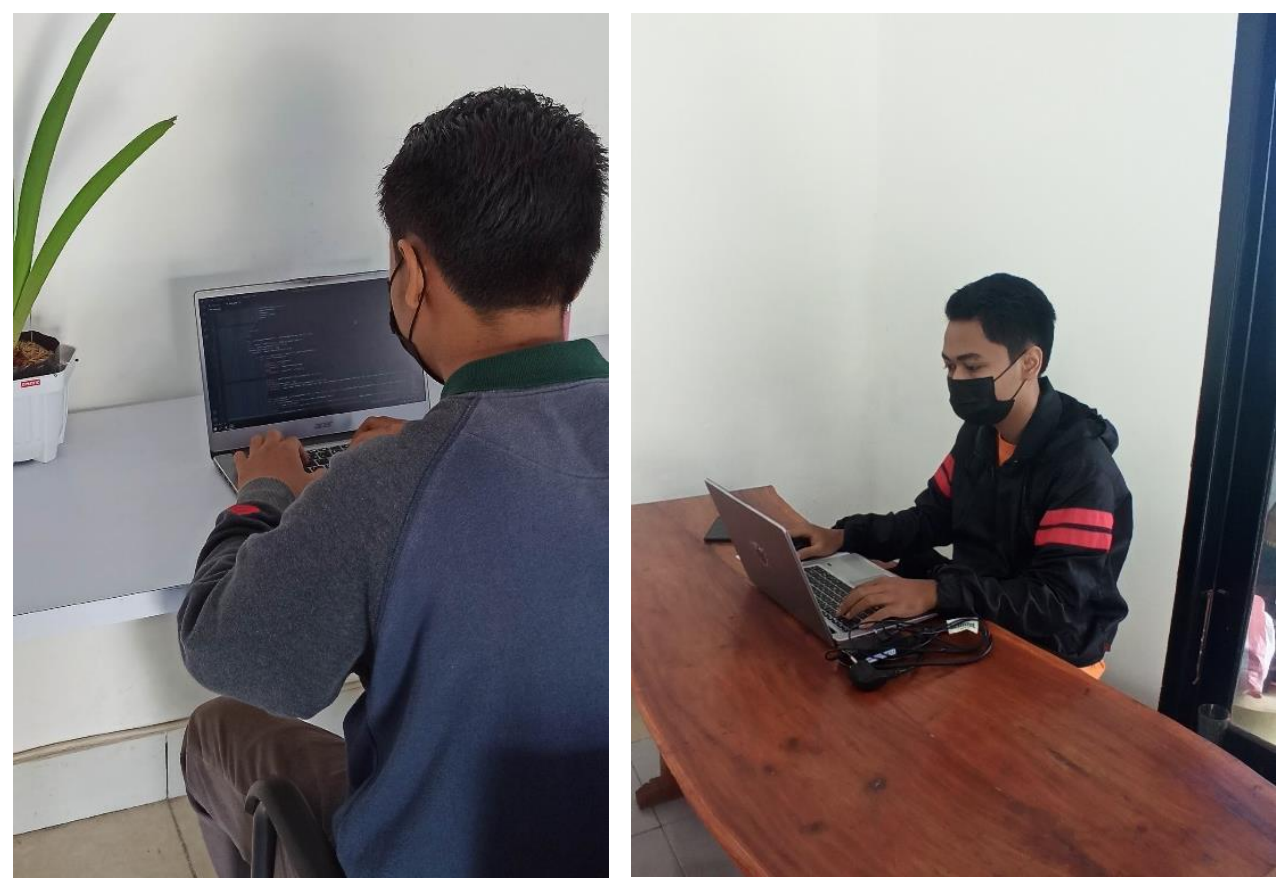

Gambar 4. Pengkodean website 
Pada gambar 4, disini saya mulai mengerjakan website yang akan saya buat, adapun media pendukung yang saya gunakan antara lain:
1) Laptop Acer Core i5
2) Visual Studio Code
3) XAMPP

4) Tampilan Antarmuka

Berikut ini merupakan beberapa tampilan dari antarmuka sistem yang telah selesai dirancang:

1) Halaman Login Admin

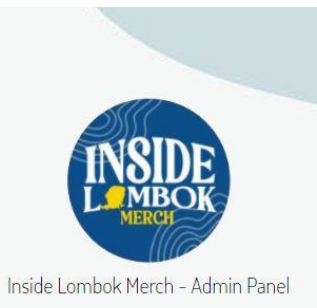

Masuk
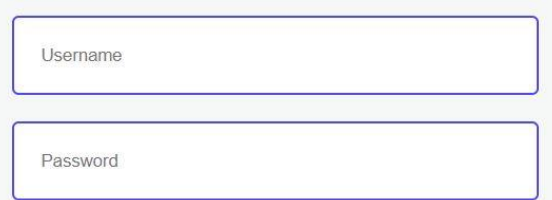

Masuk

Gambar 5. Halaman Login Admin

Pada gambar 5, halaman login admin dapat memasukkan username dan password untuk dapat mengakses dahsboard dari admin website. 
2) Halaman Dashboard Beranda Admin

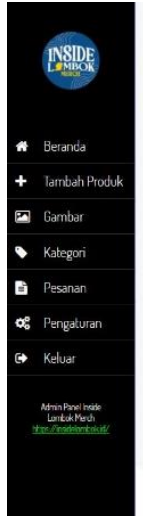

Beranda

- Telah Terbit

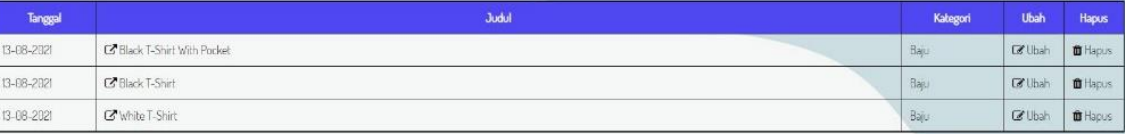

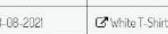

Gambar 6. Halaman Dashboard Beranda Admin

Pada gambar 6, halaman beranda ini akan menampilkan posting dari produk yang telah diinputkan oleh admin ke website Inside Lombok Merchandise.

3) Halaman Tambah Produk

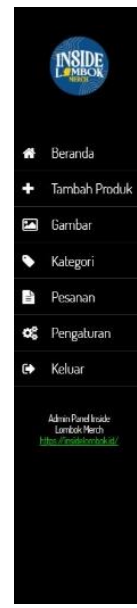

Tambah Produk

Tambah

Juatil

๒खargo

Haroa

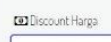

Discount Harga

-

Tonter

File - Edh - New - Format - Trools -

$\pi \pi \cdot$

Gambar 7. Halaman Tambah Produk

Pada gambar 7, halaman ini admin dapat membuat postingan baru atau menambahkan produk ke website Inside Lombok Merchandise. Disini admin dapat menambahkan Judul Produk, Harga, Diskon, Kategori, Konten, Gambar, Gambar Tambahan, dan Opsi. 
4) Halaman Gambar
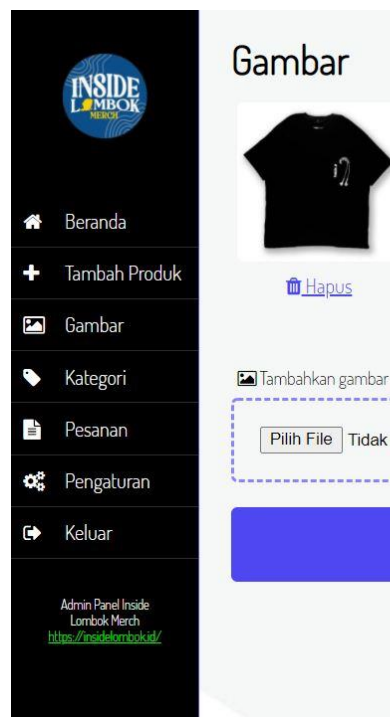

孟 Hapus

Tanbahkan gambar lain

Pilih File Tidak ada file yang dipilih

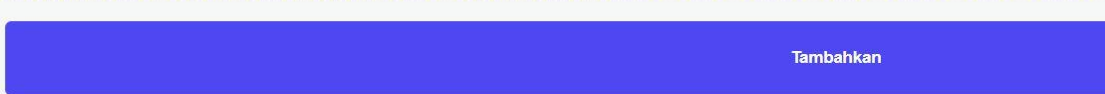

Gambar 8. Halaman Gambar

Pada gambar 8, halaman ini akan menampilkan semua gambar yang telah diinputkan ke website.

5) Halaman Kategori

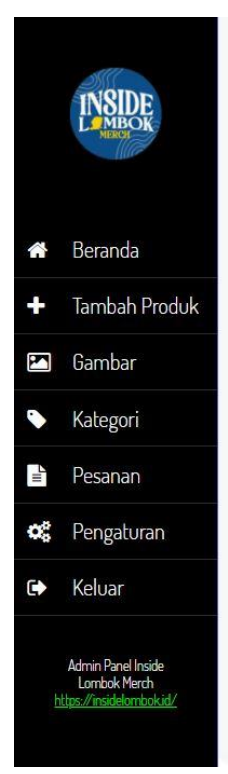

Kategori

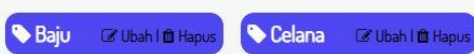

- Kategoribaru

Kategori baru

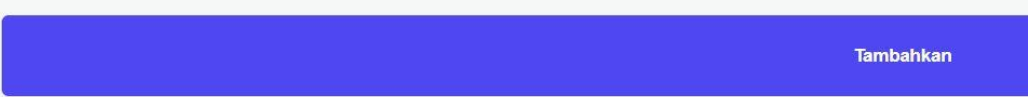

Gambar 9. Halaman Kategori 
Pada gambar 9, halaman ini merupakan halaman untuk menambahkan kategori pada produk, nanti kategori ini akan memfilter setiap kategori produknya.

6) Halaman Pesanan

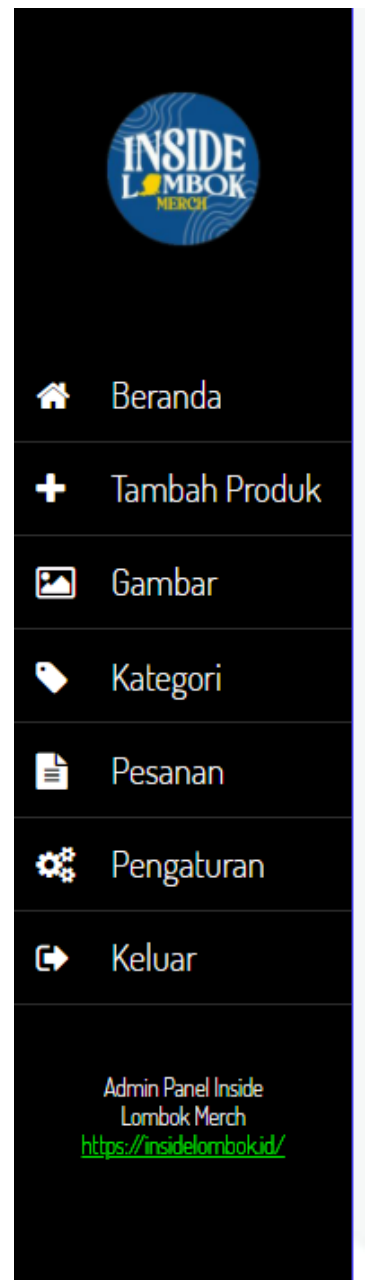

\section{Pesanan}

Belum ada order masuk.

\section{Gambar 10. Halaman Pesanan}

Pada gambar 10, halaman ini akan menampilkan pesanan yang telah diinputkan oleh pelanggan sesuai format pembelian. 
7) Halaman Pengaturan

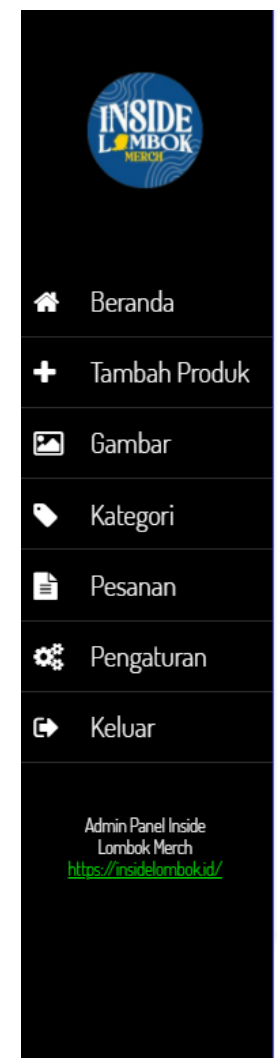

\section{Pengaturan}

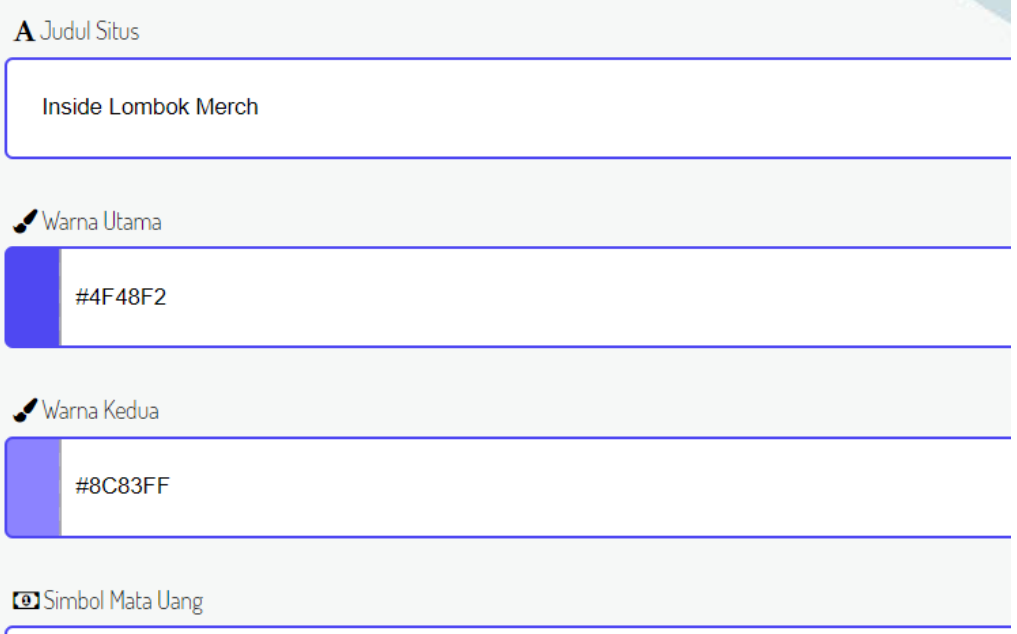

@Simbol Mata Uang

$\mathrm{Rp}$

ฮ. Sembunyikan Desimal

Tidak

\section{Gambar 11. Halaman Pengaturan}

Pada gambar 11, halaman ini admin dapat mengatur tema maupun tittle dari website. 
8) Halaman Utama Website

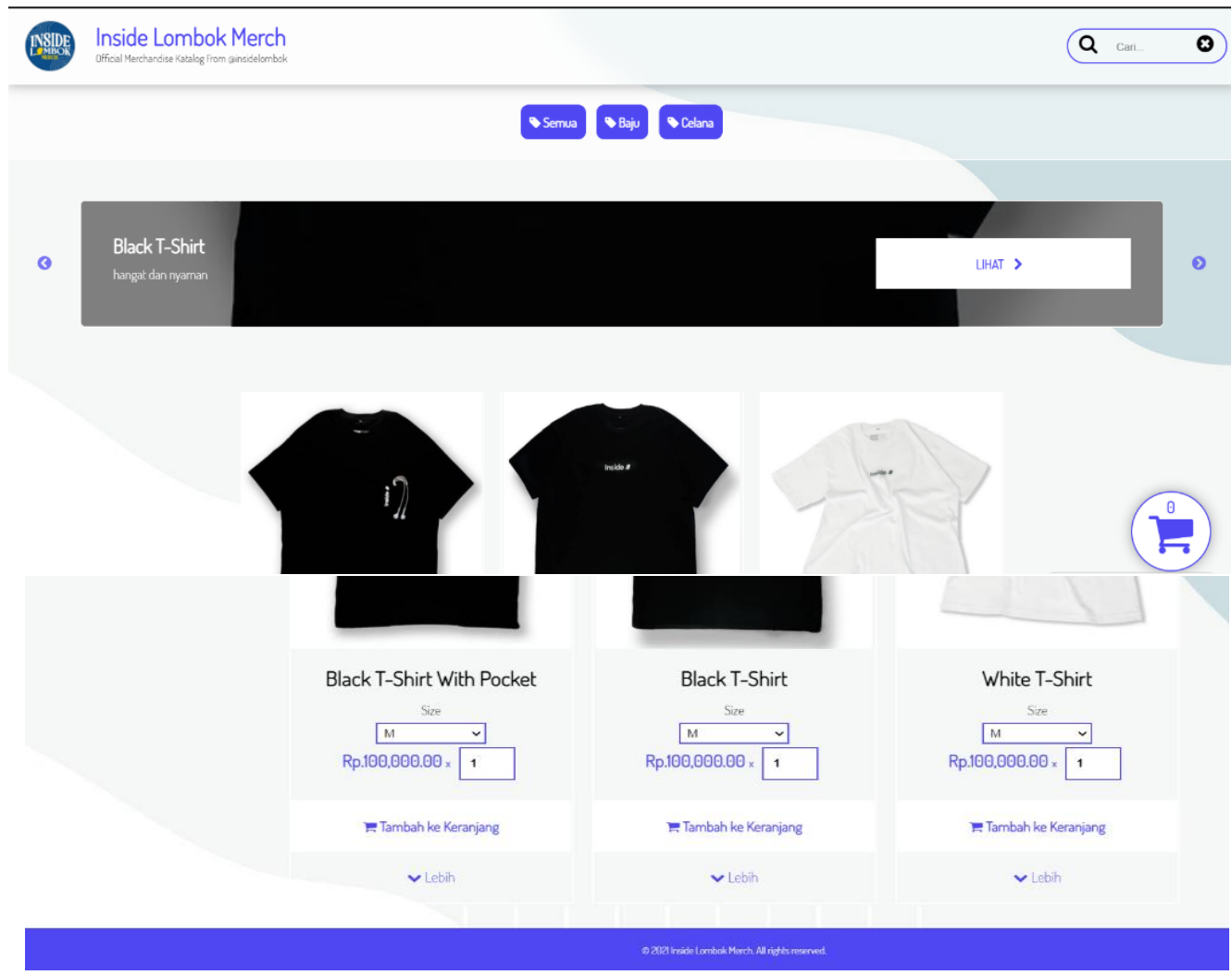

Gambar 12. Tampilan Halaman Utama Website

Pada gambar 12, halaman ini menampilkan kategori dari produk yang telah ditambah kan dan berbagai produk yang telah diposting oleh admin. Disini pelanggan dapat melihat produk, memilih size, menentukan jumlah pembelian, memesan. Terdapat gambar keranjang yang dimana disana merupakan tempat proses checkout dengan menambahkan data sesuai dengan format yang telah ditentukan. 
9) Halaman Tampilan Produk

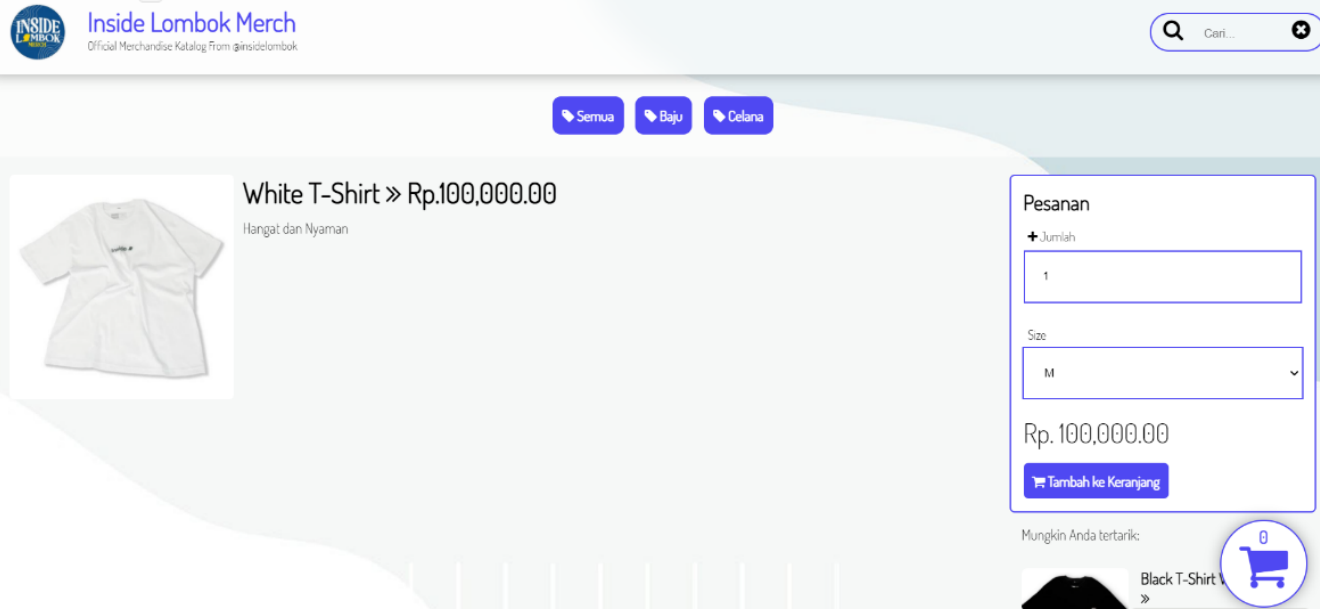

Gambar 13. Halaman Tampilan Produk

Pada gambar 13, halaman ini akan menampilkan deskripsi lengkap dari produk yang telah diklik dari halaman utama, disini juga dapat melakukan checkout. 
10) Halaman Checkout

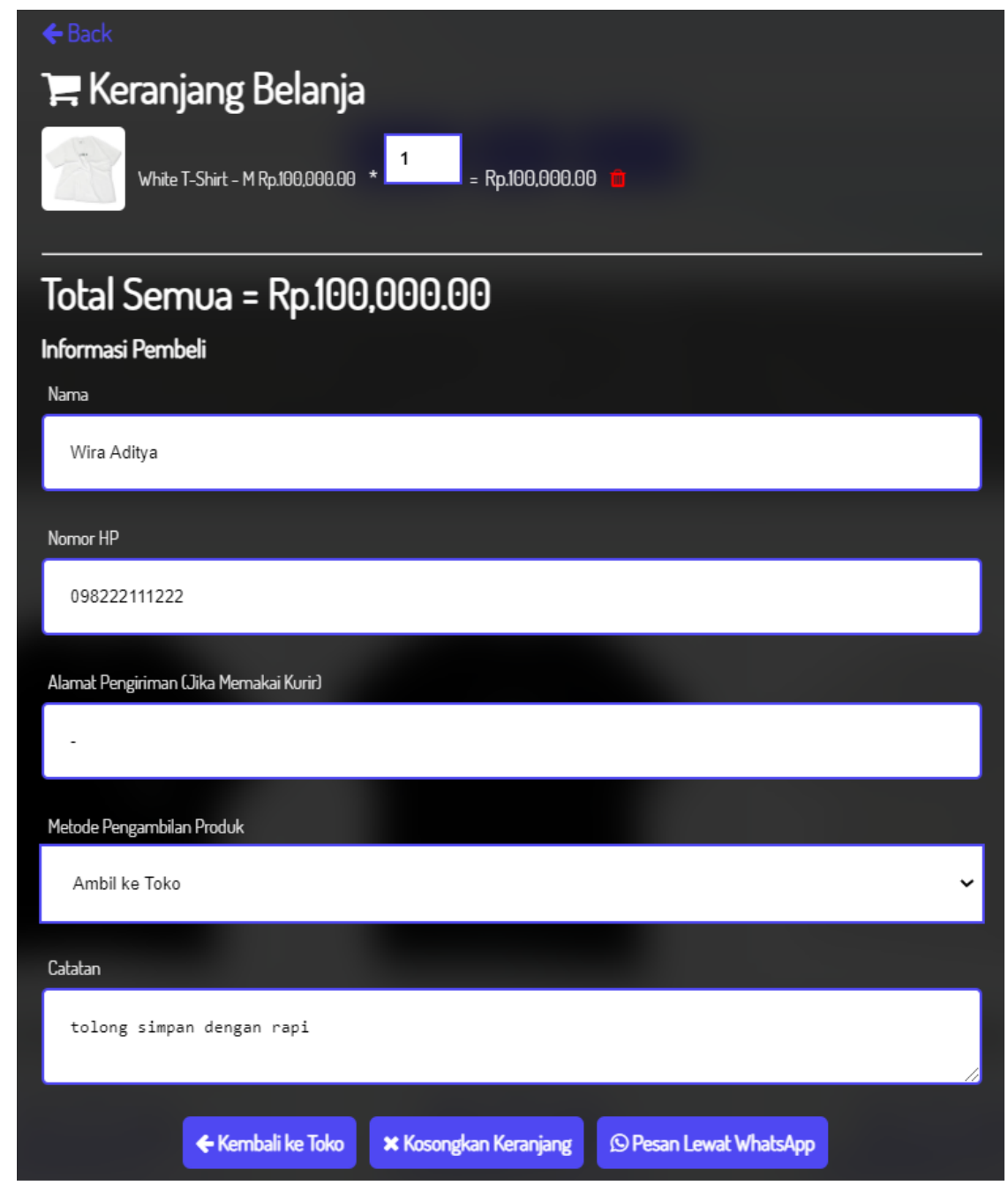

\section{Gambar 14. Tampilan Checkout}

Pada gambar 14, halaman ini pelanggan harus menambahkan data sesuai dengan format yang telah ditentukan. Setelah semua diiisi, maka selanjutnya diklik "Pesan Lewat Whatsapp". Kemudian akan dialihkan ke Whatsapp.

5) Implementasi API WhatsApp

Implementasi API WhatsApp ini terjadi ketika pelanggan mengisi format pembelian yang berada di tampilan Checkout. 


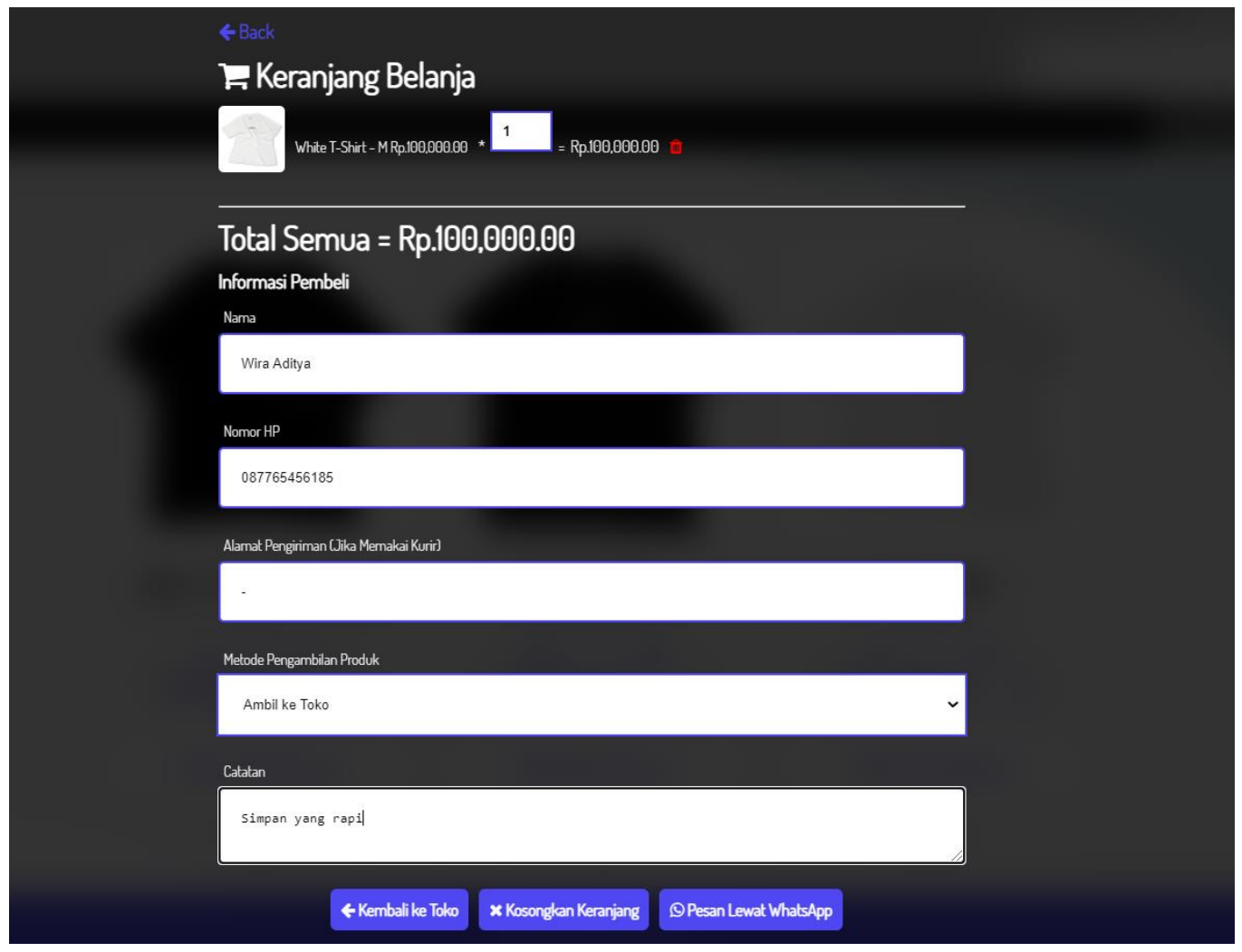

Gambar 15. Tampilan Checkout

Pada gambar 15, setelah semua terisi maka pelanggan dapat mengklik tombol / button "Pesan Lewat WhatsApp". Secara otomatis membuka WhatsApp dan langsung menghubungi Admin Inside Lombok Merchandise di WhatsApp.

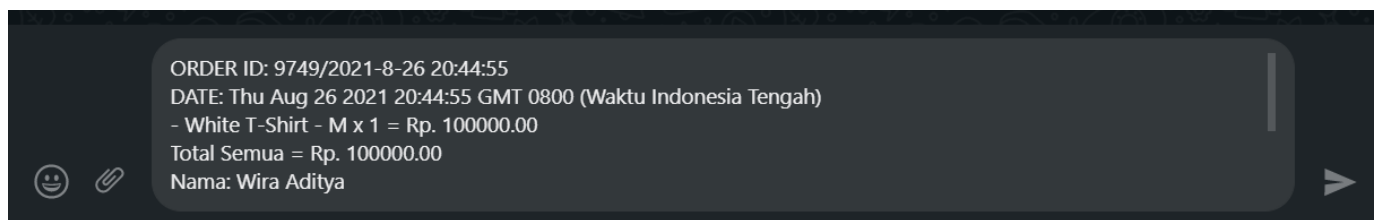

Gambar 16. Tampilan Ketikan Pesan

Pada gambar 16, maka API WhatsApp berhasil disambungkan dari website ke WhatsApp dengan berisi pesan format order yang telah diinputkan tadi tanpa harus mengetik lagi. 
ORDER ID: 9749/2021-8-26 20:44:55

DATE: Thu Aug 262021 20:44:55 GMT 0800 (Waktu Indonesia Tengah)

- White T-Shirt - M x 1 = Rp. 100000.00

Total Semua $=$ Rp. 100000.00

Nama: Wira Aditya

Nomor HP: $0 \mathcal{E}$

Alamat: -

Metode Pengambilan Produk: Ambil ke Toko

ORDER NOTES: Simpan yang rapi

\section{Gambar 17. Tampilan Pesan Terkirim}

Pada gambar 17, setelah itu pelanggan hanya tinggal send saja. Semua sudah sesuai dengan format pembelian dari website Inside Lombok Merchandise.

Setelah semua tahap perancangan diselesaikan, maka selanjutnya akan dilakukan pengujian terhadap rancangan website yang telah diselesaikan. Pengujian akan dilakukan oleh admin Inside Lombok Merch dan akan menguji berdasarkan kebutuhan yang telah ditentukan yaitu Admin dan Pelanggan, kemudian admin Inside Lombok Merchandise akan mencoba apakah sistem sudah sesuai berdasarkan sudut pandang Admin dan sudut pandang Pelanggan.

\section{b. Evaluasi Sistem}

Untuk tahap terakhir, penulis menggunakan blackbox testing untuk menguji apakah input dan output pada sistem telah memenuhi kebutuhan terkait dengan internal program serta memberikan angket kepuasan terhadap penggunaan website Inside Lombok Merchandise.

1. Evaluasi Black Box Testing

Adapun hasil pengujian dan evaluasi di sajikan pada tabel 1 dan tabel 2 di bawah ini.

\begin{tabular}{|c|c|c|c|c|c|}
\hline No & Nama Proses & Aktor & Aksi & $\begin{array}{l}\text { Hasil Yang } \\
\text { Diharapkan }\end{array}$ & Hasil \\
\hline 1 & Login & Admin & $\begin{array}{l}\text { Melakukan } \\
\text { login dengan } \\
\text { memasukkan } \\
\text { username } \\
\text { dan } \\
\text { password }\end{array}$ & $\begin{array}{l}\text { Aktor dapat } \\
\text { masuk ke } \\
\text { dalam sistem } \\
\text { admin }\end{array}$ & Berhasil \\
\hline 2 & $\begin{array}{l}\text { Mengelola } \\
\text { Produk }\end{array}$ & Admin & $\begin{array}{l}\text { Melakukan } \\
\text { pengelolaan }\end{array}$ & $\begin{array}{l}\text { Admin dapat } \\
\text { mengelola data } \\
\text { diubah, }\end{array}$ & Berhasil \\
\hline
\end{tabular}




\begin{tabular}{|c|c|c|c|c|c|}
\hline & & & $\begin{array}{l}\text { CRUD pada } \\
\text { data produk }\end{array}$ & $\begin{array}{l}\text { dihapus, } \\
\text { disimpan }\end{array}$ & \\
\hline 3 & $\begin{array}{c}\text { Mengelola } \\
\text { Kategori }\end{array}$ & Admin & $\begin{array}{l}\text { Melakukan } \\
\text { pengelolaan } \\
\text { CRUD pada } \\
\text { kategori }\end{array}$ & $\begin{array}{l}\text { Admin dapat } \\
\text { mengelola } \\
\text { Kategori } \\
\text { sehingga dapat } \\
\text { disimpan, } \\
\text { diubah,dihapus }\end{array}$ & Berhasil \\
\hline 4 & $\begin{array}{l}\text { Mengubah } \\
\text { Pengaturan }\end{array}$ & Admin & $\begin{array}{l}\text { Mengatur } \\
\text { tampilan } \\
\text { pada } \\
\text { Website } \\
\text { utama }\end{array}$ & $\begin{array}{l}\text { Admin dapat } \\
\text { mengelola } \\
\text { Tampilan } \\
\text { website utama } \\
\text { sehingga dapat } \\
\text { diubah pada } \\
\text { tampilan, } \\
\text { warna, tulisan }\end{array}$ & Berhasil \\
\hline 5 & $\begin{array}{l}\text { Melihat } \\
\text { Produk }\end{array}$ & Admin & $\begin{array}{l}\text { Melihat } \\
\text { produk dan } \\
\text { mengetahui } \\
\text { informasi } \\
\text { detail dari } \\
\text { produk }\end{array}$ & $\begin{array}{l}\text { Admin dapat } \\
\text { melihat produk } \\
\text { dan } \\
\text { mengetahui } \\
\text { detail dari } \\
\text { produk tersebut }\end{array}$ & Berhasil \\
\hline 6 & $\begin{array}{l}\text { Konfirmasi } \\
\text { Status } \\
\text { Pembayaran }\end{array}$ & Admin & $\begin{array}{l}\text { Melakukan } \\
\text { Pengecekan } \\
\text { terhadap } \\
\text { pembayaran } \\
\text { yang } \\
\text { dilakukan } \\
\text { oleh } \\
\text { pelanggan }\end{array}$ & $\begin{array}{l}\text { Admin dapat } \\
\text { mengkonfirmasi } \\
\text { status } \\
\text { pembayaran } \\
\text { produk }\end{array}$ & Berhasil \\
\hline
\end{tabular}

Setelah dilakukannya pengujian dan evaluasi pada tabel 1 menunjukkan bahwa fungsionalitas pada website Inside Lombok Merchandise telah berhasil dan bekerja dengan baik sesuai dengan proses perancangan.

Tabel 2. Tabel BlackBox Testing Pelanggan

\begin{tabular}{ccclll}
\hline No & $\begin{array}{c}\text { Nama } \\
\text { Proses }\end{array}$ & Aktor & \multicolumn{1}{c}{ Aksi } & $\begin{array}{l}\text { Hasil Yang } \\
\text { Diharapkan }\end{array}$ & Hasil \\
\hline 1 & Melihat & Pelanggan & Melihat & Admin dan & Berhasil \\
& Produk & & $\begin{array}{l}\text { produk dan } \\
\text { mengetahui }\end{array}$ & $\begin{array}{l}\text { pelanggan } \\
\text { melihat produk }\end{array}$ & \\
& & & informasi & dan & \\
& & & detail dari & mengetahui & \\
& & produk & detail dari & \\
& & & produk & \\
& & & tersebut &
\end{tabular}




\begin{tabular}{|c|c|c|c|c|c|}
\hline 2 & $\begin{array}{l}\text { Checkout } \\
\text { Order }\end{array}$ & Pelanggan & $\begin{array}{l}\text { Menampilkan } \\
\text { Halaman } \\
\text { Checkout }\end{array}$ & $\begin{array}{l}\text { Pelanggan } \\
\text { dapat } \\
\text { menambahkan } \\
\text { barang di } \\
\text { Checkout }\end{array}$ & Berhasil \\
\hline 3 & $\begin{array}{l}\text { Input Format } \\
\text { Order }\end{array}$ & Pelanggan & $\begin{array}{l}\text { Menginputkan } \\
\text { format } \\
\text { pembelian }\end{array}$ & $\begin{array}{l}\text { Pelanggan } \\
\text { dapat mengisi } \\
\text { format } \\
\text { Dembelian }\end{array}$ & Berhasil \\
\hline 4 & $\begin{array}{l}\text { Konfirmasi } \\
\text { Pembayaran }\end{array}$ & Pelanggan & $\begin{array}{l}\text { Melakukan } \\
\text { pembayaran } \\
\text { terhadap } \\
\text { produk }\end{array}$ & $\begin{array}{l}\text { Pelanggan } \\
\text { memberikan } \\
\text { konfirmasi } \\
\text { pembayaran } \\
\text { ke admin }\end{array}$ & Berhasil \\
\hline
\end{tabular}

\section{c. Pelatihan}

Setelah dilakukannya pengujian kepada website yang telah dibuat, maka selanjutnya tim akan memberikan pelatihan kepada admin staff Inside Lombok Merch dalam menggunakan website. Tim memberikan pelatihan terhadap fitur yang ada pada website yaitu Admin dan Pelanggan, tim memberikan pelatihan tentang alur dalam mengakses admin pada website berupa mengelola produk dan mengecek pesanan, menampilkan produk, menerima pesanan, dan konfirmasi status pembayaran. Kemudian untuk fitur Pelanggan, tim memberikan pelatihan kepada admin staff Inside Lombok Merch terhadap penggunaan website utama dalam hal menampilkan produk dan menambah produk ke checkout, serta mengisi format pemesanan pada checkout dan fitur WhatsApp yang menghubungkan format pembelian ke chat admin. Selanjutnya tim memberikan angket kepuasan kepada admin staff Inside Lombok Merchandise.

Respon kepuasan ini ditujukan untuk melihat apakah website yang telah dirancang sudah memberikan kepuasan, baik dari segi kinerja untuk admin dan kepuasan terhadap informasi untuk pelanggan. Pertanyaan disajikan dalam bentuk angket, adapun hasil dari angket terkait kepuasan dalam penggunaan website, kemudian dinilai sesuai pernyataan yang tersedia oleh staff admin yang dipandu oleh tim sebagai perancang website disajikan pada tabel 3 dan 4 di bawah ini. 
Tabel 3. Angket Evaluasi Kepuasan Admin

\begin{tabular}{|c|c|c|c|c|c|c|}
\hline No & Uji Kasus & $\begin{array}{c}\text { Pernyataan } \\
\text { Terkait }\end{array}$ & $\begin{array}{l}\text { Sangat } \\
\text { Puas }\end{array}$ & Puas & $\begin{array}{l}\text { Tidak } \\
\text { Puas }\end{array}$ & $\begin{array}{c}\text { Sangat } \\
\text { Tidak } \\
\text { Puas }\end{array}$ \\
\hline 2 & $\begin{array}{l}\text { Penggunaan } \\
\text { website admin } \\
\text { oleh admin }\end{array}$ & $\begin{array}{l}\text { Mengelola } \\
\text { Produk } \\
\text { Mengecek } \\
\text { Pesanan }\end{array}$ & $\checkmark$ & $\checkmark$ & & \\
\hline 3 & $\begin{array}{c}\text { Pengunaan } \\
\text { website utama }\end{array}$ & $\begin{array}{l}\text { Menampilkan } \\
\text { produk }\end{array}$ & & $\downarrow$ & & \\
\hline 4 & & $\begin{array}{l}\text { Menerima } \\
\text { Pesanan }\end{array}$ & $\checkmark$ & & & \\
\hline 5 & WhatsApp & $\begin{array}{l}\text { Konfirmasi } \\
\text { Status } \\
\text { Pembayaran }\end{array}$ & $\checkmark$ & & & \\
\hline
\end{tabular}

Berdasarkan hasil angket evaluasi pada tabel 3 di atas, menunjukkan bahwa telah memberikan kepuasan kepada admin terhadap penggunaan website dalam mengelola produk, mengecek pesanan, menampilkan produk terbaru. Selanjutnya angket evaluasi terhadap pelanggan disajikan pada tabel 4 untuk melihat bagaimana kepuasan pelanggan dalam menggunakan website yang telah dirancang.

Tabel 4. Angket Evaluasi Kepuasan Pelanggan

\begin{tabular}{|c|c|c|c|c|c|c|}
\hline No & Uji Kasus & $\begin{array}{c}\text { Pernyataan } \\
\text { Terkait }\end{array}$ & $\begin{array}{c}\text { Sangat } \\
\text { Puas }\end{array}$ & Puas & $\begin{array}{l}\text { Tidak } \\
\text { Puas }\end{array}$ & $\begin{array}{c}\text { Sangat } \\
\text { Tidak } \\
\text { Puas }\end{array}$ \\
\hline 1 & & $\begin{array}{l}\text { Menampilkan } \\
\text { Produk }\end{array}$ & $\checkmark$ & & & \\
\hline 2 & $\begin{array}{l}\text { Penggunaan } \\
\text { website utama }\end{array}$ & $\begin{array}{l}\text { Menambah } \\
\text { Produk Ke } \\
\text { Checkout }\end{array}$ & $\checkmark$ & & & \\
\hline 3 & Checkout & $\begin{array}{l}\text { Mengisi } \\
\text { Format } \\
\text { Pemesanan }\end{array}$ & $\checkmark$ & & & \\
\hline 4 & WhatsApp & $\begin{array}{l}\text { Terhubung } \\
\text { Langsung } \\
\text { Sesuai }\end{array}$ & & $\checkmark$ & & \\
\hline
\end{tabular}




Dengan
Format
Pemesanan
Konfirmasi
Pembayaran
Berdasarkan hasil angket evaluasi pada tabel 4 di atas, menunjukkan bahwa telah
berikan kepuasan kepada pelanggan terhadap penggunaan website utama dalam hal
checkout telah memberikan hasil yang memuaskan dan fitur WhatsApp telah
mberikan kepuasan dalam hal menghubungkan format pembelian ke chat admin.

\section{d. Kendala yang Terekam}

Dalam proses pembuatan website ini terdapat kendala yang dihadapi yaitu dalam perancangan prototype, ada ketidakcocokan dengan tampilan yang diinginkan. Sehingga perlu adanya revisi dengan merancang ulang tampilan sesuai dengan tampilan yang diinginkan. Serta dalam mengimplementasikan API WhatsAPP untuk menghubungkan website dengan whatsapp, terdapat error yang dihadapi karena nomor yang telah dihubungkan kadang dinyatakan tidak diketahui.

\section{KESIMPULAN}

Berdasarkan hasil perancangan website dan testing yang telah dilakukan dari Perancangan Sistem Informasi Website Merchandise Inside Lombok ini dapat ditarik kesimpulan yaitu website yang telah dihasilkan mampu memberikan kemudahan kepada admin dalam mengelola produk yang ada pada website dan bagi pelanggan yang ingin membeli merchandise dalam menginput format pembelian dapat dimudahkan dengan adanya fitur API WhatsApp pada website.

Adapun saran yang dapat diberikan yaitu perlunya menambah akses untuk login pelanggan guna untuk menambah whistlist yang diinginkan oleh pelanggan. Serta diharapkan dapat melakukan proses pembayaran langsung pada website.

\section{UCAPAN TERIMA KASIH (Bila Perlu)}

Penulis mengucapkan terima kasih kepada $x x x$ yang telah memberi dukungan financial terhadap pengabdian ini. 


\section{DAFTAR PUSTAKA}

Abidatul Izzah. (2021). Pengembangan Web Company Profile Terintegrasi Dengan Api Whatsapp (Studi Kasus: Agen Sembako Al-Barkah). INFOTECH Journal, 40-44. https://doi.org/10.31949/infotech.v7i1.1067

Anis Rohmadi, V. Y. (2020). Desain dan Penerapan Website Tata Kelola Percetakan Pada CV APICDESIGN KREASINDO JAKARTA dengan Metodey Prototyping. Journal of Information System, Infomatics and Computing, 4(1), 70-85.

Aprilia, S. (2020). Sistem Informasi Absensi Berbasis Website Menggunakan API WhatsApp dengan Metodologi Incremental (Studi Kasus: SMP Negeri 29 Pekanbaru). Journal of Applied Informatics and Computing, 4(1), 38-44. https://doi.org/10.30871/jaic.v4i1.1966

Hasan, M. A., \& Nasution, N. (2018). Rancang Bangun Aplikasi Pembuatan Web Blog Berbasis Web Menggunakan HTML5. INOVTEK Polbeng - Seri Informatika, 3(1), 68. https://doi.org/10.35314/isi.v3i1.362

Lesmono, I. D. (2018). Rancang Bangun Sistem Informasi Penjualan Sepatu Berbasis Website Dengan Metode Waterfall. Swabumi, 6(1), 55-62. https://doi.org/10.31294/swabumi.v6i1.3316

Mariko, S. (2019). Aplikasi website berbasis HTML dan JavaScript untuk menyelesaikan fungsi integral pada mata kuliah kalkulus. Jurnal Inovasi Teknologi Pendidikan, 6(1), 80-91. https://doi.org/10.21831/jitp.v6i1.22280

Nasir, M., \& Solikin, I. (2019). Rancang Bangun E- Commerce Toko Raffamart Palembang Menggunakan Macromedia Dreamweaver. Jurnal IImiah Matrik, 20(3), 247-257. https://doi.org/10.33557/jurnalmatrik.v20i3.473

Peni, S., Handayani, M., \& Purnama, B. E. (2013). Pembuatan Website E-Commerce Pada Distro Java Trend. Seminar Riset Unggulan Nasional Informatika Dan Komputer, 18-24.

Pradipta, A. A. dk. (2019). Pengembangan Web E-Commerce Bojana Sari Menggunakan Metode Prototype. Jurnal Tugas Akhir / Fakultas Rekayasa Industri, 3(1), 341-347.

Ruswiansari, M., \& Rozi, N. F. (2018). Pengembangan Aplikasi Pembelajaran Untuk Topik HTML 5 Menggunakan Model User-Centered Design. Jurnal ELTIKOM, 2(2), 94-101. https://doi.org/10.31961/eltikom.v2i2.83

Saragih, S. P. (2020). Rancang Bangun Sistem Informasi Penjualan Berbasis Web Pada Cv Multi Mandiri. Khazanah IImu Berazam, 163-174.

Siregar, V. M. M. (2018). Perancangan Website Sebagai Media Promosi Dan Penjualan Produk. TAM (Technology Acceptance Model), 9(1), 15-21.

Susilo, M. (2018). Rancang Bangun Website Toko Online Menggunakan Metode Waterfall. InfoTekJar (Jurnal Nasional Informatika Dan Teknologi Jaringan), 2(2), 98-105. https://doi.org/10.30743/infotekjar.v2i2.171

Wahyudi, I., Bahri, S., \& Handayani, P. (2019). Aplikasi Pembelajaran Pengenalan Budaya Indonesia. V(1), 135-138. https://doi.org/10.31294/jtk.v4i2

Websitedi, B., Wahyu, C. V, Berguna, A., Lantai, G. P., Jl, K., Timur, S., \& Syahrulyogagmailcom, E. (2020). Sistem Informasi Penjualan Menggunakan Crud. 5(Sens 5), 843-851. 